\title{
Aktivitas Ekstrak Etanol 70\% Biji Nangka (Artocarpus heterophyllus Lam.) dalam Penurunan Kadar Gula Darah Tikus Diabetes Gestasional Yang Diinduksi Streptozotocin
}

\author{
(Activities of Ethanol Extract 70\% Jackfruit Seeds (Artocarpus heterophyllus Lam.) In Lowering Blood \\ Sugar Levels on Diabetic Rats Gestational Induced by Streptozotocin)
}

Penulis

Afiliasi

\author{
Dwitiyanti*, Kriana Efendi, Rizky Arcinthya Rachmania, Riri Septiani
}

Program Studi Farmasi, Fakultas Farmasi dan Sains, Universitas Muhammadiyah Prof. Dr. Hamka, Indonesia

\section{Kata Kunci \\ - Biji nangka \\ D Diabetes gestasional \\ S Streptozotosin}

\section{Key words \\ $\rightarrow$ Diabetic gestasional \\ כ Jacfruit seeds \\ $\rightarrow$ Streptozotocin}

Diterima 4 Oktober 2018 Direvisi 28 November 2018 Disetujui 10 Januari 2019

* Penulis Koresponding Dwitiyanti.

email: dwity.farmasi@gmail.com

\section{ABSTRAK}

Biji Buah Nangka (Artocarpus heterophyllus L.) dilaporkan memiliki aktivitas sebagai antihiperglikemia. Pada penelitian ini bertujuan menguji ekstrak etanol 70\% biji nangka dan diharapkan dapat dimanfaatkan sebagai penurun kadar gula darah tikus diabetes gestasional yang diinduksi streptozotocin. Hewan uji tikus betina bunting galur Sprague dawley dibagi 6 kelompok perlakuan, masing-masing terdiri dari 4 ekor tikus. Kelompok I (kontrol normal), kelompok II (kontrol negatif), kelompok III (kontrol positif) diberi metformin dosis $51.37 \mathrm{mg} / \mathrm{kgBB}$, kelompok IV (Dosis Uji $100 \mathrm{mg} / \mathrm{kgBB}$ ), kelompok V (Dosis Uji $200 \mathrm{mg} / \mathrm{kgBB}$ ) dan kelompok VI (Dosis Uji $400 \mathrm{mg} / \mathrm{kgBB}$ ), kelompok IV,V dan VI diberi sediaan uji biji buah nangka secara oral. Tikus diinduksi terlebih dahulu dengan streptozotocin agar tikus mengalami hiperglikemia, kemudian diberi perlakuan sediaan uji selama 14 hari. Pengambilan darah dilakukan pada hari ke-14, untuk menghitung kadar glukosa darah menggunakan fotometer klinikal. Hasil uji ANOVA satu arah menunjukkan adanya perbedaan antar kelompok perlakuan. Semua kelompok sediaan uji ekstrak biji buah nangka memiliki aktivitas menurunkan kadar glukosa darah terhadap tikus diabetes gestasional. Hasil uji Tukey penurunan kadar glukosa darah menunjukan kelompok uji sediaan biji nangka dosis $400 \mathrm{mg} / \mathrm{kg}$ BB sebanding dengan kelompok positif yang diberikan Metformin $51.37 \mathrm{mg} / \mathrm{kgBB}$.

\section{ABSTRACT}

Jackfruit Seeds (Artocarpus heterophyllus L.) are reported to have activity as antihyperglycemia. This study aims to test $70 \%$ ethanol extract of jackfruit seeds and is expected to be used as a blood sugar level lowering in gestational diabetic rats induced streptozotocin. Test animals of pregnant female rats Sprague dawley strain were divided into 6 treatment groups, each consisting of 4 rats. Group I (normal control), group II (negative control), group III (positive control) were given metformin dose $51.37 \mathrm{mg} / \mathrm{kgBB}$, group IV (dose $100 \mathrm{mg} / \mathrm{kg} \mathrm{BW}$, group V (dose $200 \mathrm{mg} / \mathrm{kg} \mathrm{BW}$ ), group VI (dose 400 $\mathrm{mg} / \mathrm{kg} B W$. Group IV,V and VI given preparations of jackfruit seed extract, and orally. The rats were induced first with streptozotocin so that the rats had hyperglycemia, then given test preparation for 14 days. Blood sampling was carried out on day 14, to calculate blood glucose levels using a clinical photometer. The oneway ANOVA test results showed differences between treatment groups. All groups of preparations for jackfruit seed extract have an activity to reduce blood glucose levels in gestational diabetic rats. Tukey test results in decreased blood glucose levels showed the test group of Jackfruit seed dose of $400 \mathrm{mg} / \mathrm{kgBW}$ was comparable to the positive group given Metformin $51.37 \mathrm{mg} / \mathrm{kgBW}$ 


\section{PENDAHULUAN}

Diabetes Mellitus Gestasional (DMG) merupakan diabetes yang terjadi pada wanita hamil karena pada saat kehamilan terjadi perubahan metabolisme karbohidrat, protein, dan lemak. Pada wanita hamil terjadi perubahan-perubahan fisiologis yang berpengaruh terhadap metabolisme karbohidrat karena adanya hormon plasenta yang bersifat resistensi terhadap insulin. Perubahan ini menyebabkan kehamilan tersebut bersifat diabetogenik, dengan meningkatnya umur kehamilan, berbagai faktor dapat mengganggu keseimbangan metabolisme karbohidrat sehingga terjadi gangguan toleransi glukosa (Buchanan 2005).

Angka kejadian DMG di Indonesia sekitar 1.9-3.6\%. Berdasarkan data Departemen Kesehatan, jumlah pasien DM rawat inap maupun rawat jalan di rumah sakit menempati urutan pertama dari seluruh penyakit endokrin dan $4 \%$ wanita hamil menderita Diabetes Mellitus Gestasional (Studiawan 2007). Berdasarkan American Diabetes Association (ADA 2009) Guidelines, seorang wanita dianggap memiliki risiko tinggi menderita DMG bila memiliki satu atau lebih dari kriteria berikut yaitu, menderita obesitas, riwayat kehamilan sebelumnya dengan DMG, memiliki intoleransi glukosa atau glukosuria, memiliki anggota keluarga dengan diabetes melitus tipe . Pengaruh DMG pada ibu yaitu dapat menyebabkan hiperglikemia dan juga beberapa komplikasi seperti retinopati, nefropati dan neuropati, sedangkan pada janin dapat terjadi gangguan pernafasan, kelainan kongenital dan makrosomia. Kelainan kongenital merupakan penyebab penting dari mortalitas perinatal (Brudenell dan Marjorie 1996).

Tatalaksana DMG dapat dilakukan melalui intervensi non farmakologis dan intervensi farmakologis. Intervensi non farmakologis diantaranya perubahan pola diet, aktivitas fisik dan menjaga berat badan. Sementara intervensi farmakologi meliputi obat antidiabetes secara oral dan pemberian insulin (ADA 2016). Penggunaan obat-obat antidiabetes dalam jangka waktu tertentu dan panjang dapat menyebabkan efek samping pada organ serta jika tidak diobati akan menyebabkan sejumlah penyakit yang pengobatannya membutuhkan biaya yang mahal. Salah satunya adalah Metformin. Metformin adalah obat hipoglikemia oral yang termasuk dalam golongan biguanid. Insiden kelahiran prematur (kurang dari usia kehamilan 37 minggu) secara signifikan lebih tinggi dengan metformin (12.1\% vs $7.6 \%)$. Seperti yang diharapkan, risiko hipoglikemia neonatal berat secara signifikan lebih rendah pada metformin (3.3\% vs $8.1 \%$ ). Sekitar $45 \%$ dari wanita DMG dengan terapi metformin membutuhkan terapi insulin tambahan untuk mencapai target glikemik (Rowan 2008). Efek samping yang paling umum adalah ketidak nyamanan perut, sakit perut, diare dan anoreksia (Triplitt et al. 2015). Oleh karna itu, perlu dikembangkannya pengobatan alternatif secara tradisional dengan bahan alam yang pengobatannya lebih murah, aman dan memberikan efek samping yang relatif rendah.

Bahan alam yang dapat digunakan sebagai pengobatan alternatif diabetes salah satunya adalah biji buah nangka (Artocarpus heterophyllus Lam.) (Zanin et al. 2012). Biji buah nangka memiliki senyawa yang berkhasiat seperti flavonoid, saponin, alkaloid, terpenoid dan steroid (Gupta et al. 2011; Asmarawati dkk 2016). Flavonoid berperan secara signifikan meningkatkan aktivitas enzim antioksidan yang dapat menetralkan radikal bebas dan mampu menurunkan kadar gula darah dan mengatasi kelelahan yang diakibatkan oleh kadar gula darah yang tak seimbang (Permana 2009). Flavonoid dapat menurunkan kadar glukosa darah dengan kemampuannya sebagai zat antioksidan dan bersifat protektif terhadap kerusakan sel ß pankreas sebagai penghasil insulin serta dapat meningkatkan sensitivitas insulin (Kaneto et al. 1999).

Nangka (Artocarpus heterophyllus Lam.) merupakan tanaman berkhasiat dan sudah banyak digunakan oleh masyarakat untuk mengobati berbagai penyakit secara turun temurun. Pada kulit batang nangka mempunyai aktivitas sebagai antibakteri (Swantara 2011). Khasiat selanjutnya yaitu ekstrak daun nangka dalam dosis $500 \mathrm{mg} / \mathrm{kgBB}$ dapat menurunkan kadar glukosa darah, kemudian penelitian yang sudah dilakukan oleh Moura et al. (2018) ekstrak etanol biji buah nangka (Artocarpus heterophyllus Lam.) mempunyai kemampuan untuk mengurangi tingkat hiperglikemia mencit pada dosis $50 \mathrm{mg} / \mathrm{kgBB}$ sebesar $32.3 \%$. Berdasarkan uraian di atas maka dilakukan penelitian aktivitas ekstrak etanol 70\% biji buah nangka terhadap penurunan kadar glukosa darah tikus DMG yang diinduksi streptozotocin yang dibandingkan dengan tikus DMG dengan terapi metformin 


\section{METODE}

Alat dan Bahan

Micropipets, centrifuge, microtube, vacuette, spektrofotometer klinikal, vortex, Bahan yang digunakan dari penelitian ini adalah biji buah nangka yang diperoleh dari Balai Penelitian Tanaman Rempah dan Obat (BALITTRO) Bogor dan telah dideterminasi di Herbarium Bogoriense Lembaga Ilmu Pengetahuan Indonesia (LIPI) Cibinong dengan nomor surat 758/IPH.I.01/If.07/III/2018, etanol 70\%, Na CMC, pereaksi Mayer dan Dragendrorf, methanol, $\mathrm{HCl} 2 \mathrm{~N}$, $\mathrm{FeCl}_{3}$, Streptozotocin (Sigma-Aldrich, Saint Louis, USA), Metformin.

\section{Determinasi Tanaman}

Tanaman biji buah nangka yang dideterminasi oleh Lembaga IImu Pengetahuan Indonesia (LIPI) Cibinong, Bogor untuk memastikan jenis dan kebenaran simplisia.

\section{Pembuatan Simplisia Serbuk Biji Buah Nangka}

Sebanyak $4 \mathrm{~kg}$ biji buah nangka diambil lalu dibersihkan dari pengotornya, kemudian dicuci dengan air hingga bersih, ditiriskan dan dirajang halus, dikeringkan di bawah sinar matahari. Setelah kering kemudian diserbukkan dan didapatkan $2 \mathrm{~kg}$ serbuk kering biji nangka, selanjutnya diayak dengan ayakan nomor 40 . Serbuk halus yang diperoleh adalah $1.7 \mathrm{~kg}$.

\section{Pembuatan Ekstrak Etanol 70\%}

Ekstraksi biji buah nangka dilakukan dengan cara maserasi karena ekstraksi dengan cara ini merupakan cara penyarian yang sederhana dan tidak berpotensi merusak zat aktif tanaman. Maserasi dilakukan dengan cara serbuk biji buah nangka ditimbang sebanyak $1 \mathrm{~kg}$, kemudian diekstraksi dengan larutan etanol 70\% sebanyak $10 \mathrm{~L}$ dan rendam selama 6 jam, kemudian didiamkan sampai 3 hari terlindung dari cahaya disertai dengan pengadukan yang bertujuan untuk meratakan seluruh bagian serbuk simplisia agar terendam dengan etanol 70\%. Setelah 9 hari, kemudian dilakukan penyaringan, ampasnya dilakukan maserasi kembali dengan etanol $70 \%$ dengan prosedur yang sama. Maserat yang didapatkan kemudian diuapkan dengan menggunakan vacum rotary evaporator hingga didapat ekstrak kental etanol 70\% (Depkes RI 2008).

\section{Pemeriksaan Karakteristik Mutu Ekstrak \\ Pemeriksaan Organoleptis}

Pemeriksaan organoleptis meliputi pemeriksaan bentuk, bau, dan warna terhadap ekstrak (Depkes RI 2008).

\section{Penetapan Susut Pengeringan}

Penetapan susut pengeringan dilakukan untuk mengetahui besarnya senyawa yang hilang pada proses pengeringan (Depkes 2000). Susut pengeringan dilakukan dengan cara menimbang ekstrak sebanyak 2 gram kemudian dimasukkan ke dalam botol timbang bertutup yang sebelumnya telah dipanaskan pada suhu $105{ }^{\circ} \mathrm{C}$ selama 30 menit dan telah ditara. Sebelum ditimbang, ekstrak diratakan dalam botol timbang.

Selanjutnya botol timbang berisi ekstrak dimasukkan ke dalam oven dengan dibuka tutupnya, dikeringkan pada suhu $105^{\circ} \mathrm{C}$ hingga bobot konstan. Setiap sebelum pengeringan, botol dibiarkan dalam keadaan tertutup dan mendingin di dalam desikator hingga suhu kamar (Depkes 2000). Perhitungan persentase susut pengeringan dapat dilihat sebagai berikut:

$$
\text { Susut Pengeringan }(\%)=\frac{a-b}{a-c}
$$

Keterangan: $a=$ berat awal simplisia $(g), b=$ berat akhir simplisia (g), $\mathrm{c}=$ berat botol kosong ( $\mathrm{g}$ )

Perhitungan Persentase Rendemen Ekstrak

Perhitungan persentase rendemen dihitung dengan cara menghitung jumlah ekstrak yang diperoleh kemudian dibagi dengan jumlah serbuk simplisia sebelum dilakukan ekstraksi, kemudian dikalikan $100 \%$ (Depkes RI 2008).

Persentase Rendemen Ekstrak terhadap Simplisia

$$
=\frac{a}{b} \times 100 \%
$$

Keterangan: $a=$ berat ekstrak kental $(g), b=$ berat simplisia (g)

\section{Penapisan Fitokimia Ekstrak Metode Uji Warna (Depkes RI 1997)}

Pemeriksaan Flavonoid

Sebanyak 100 mg ekstrak dididihkan dalam $100 \mathrm{ml}$ air panas selama 5 menit dan saring. Kemudian ditambahkan $5 \mathrm{ml}$ filtrat dengan serbuk $\mathrm{Mg}$ dan $1 \mathrm{ml}$ $\mathrm{HCL}_{(\mathrm{p})}$ kocok kuat. Adanya flavonoid ditunjukkan dengan terbentuknya warna merah, kuning, atau jingga.

\section{Pemeriksaan Saponin}

Sebanyak 100 mg ekstrak dimasukkan ke dalam tabung reaksi, tambahkan $10 \mathrm{ml}$ air panas, dinginkan, 
kemudian kocok kuat-kuat selama 10 detik. Adanya saponin ditunjukkan dengan terbentuknya buih setinggi $\pm 3 \mathrm{~cm}$ dan pada penambahan HCL buih tidak hilang.

Pemeriksaan Tanin

Sebanyak $100 \mathrm{mg}$ ekstrak dididihkan dalam $50 \mathrm{ml}$ air selama 15 menit, dinginkan. Saring filtrat dengan kertas saring, lalu tambahkan 2 tetes $\mathrm{FeCl}_{3} 1 \%$. Adanya tanin ditunjukan dengan terbentuknya warna biru tua (tanin galat) atau hijau kehitaman (tanin katekuat) dan pada penambahan gelatin terbentuk endapan putih.

Pemeriksaan Alkaloid

Sebanyak 100 mg ekstrak ditambahkan dengan $1 \mathrm{ml}$ $\mathrm{HCL} 2 \mathrm{~N}$ dan $9 \mathrm{ml}$ aquadest dalam tabung reaksi, panaskan di atas penangas air pada suhu $100^{\circ} \mathrm{C}$ selama 2 menit, dinginkan dan saring. Bagi filtrat kedalam dua tabung reaksi. Tabung pertama diberi pereaksi Dragendorf, adanya alkaloid ditunjukkan dengan terbentuknya endapan merah. Tabung kedua diberi pereaksi Mayer, adanya alkaloid ditunjukkan dengan terbentuknya endapan berwarna putih.

Pemeriksaan Terpenoid dan Steroid

Sebanyak 100 mg ekstrak ditambahkan dengan $2 \mathrm{ml}$ etanol dalam tabung reaksi, dipanaskan sebentar, kemudian dinginkan dan saring. Filtrat diuapkan lalu tambahkan eter, 3 tetes asam asetat anhidrat dan 1

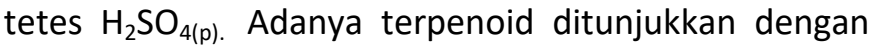
terjadinya perubahan warna menjadi merah atau ungu dan adanya steroid ditunjukkan dengan terbentuknya warna hijau.

\section{Induksi Streptozotosin dan Uji Aktivitas}

Penelitian ini sudah mendapatkan persetujuan komisi Etik dari KEPK UHAMKA dengan nomor : $02 / 18.05 / 003$. Hewan yang digunakan dalam penelitian ini adalah tikus putih betina bunting galur Sprague dawley yang dibagi menjadi enam kelompok masingmasing terdiri dari 4 ekor tikus yaitu kelompok kontrol normal, kontrol negatif, kontrol positif menggunakan metformin dosis $51,37 \mathrm{mg} / \mathrm{kgBB}$, kelompok uji dengan variasi dosis (100mg/kgBB, 200mg/kgBB, 400mg/kgBB). Sebelum diberikan perlakuan tikus di aklimatisasi terlebih dahulu selama 1 minggu agar dapat beradaptasi dengan lingkungan baru. Tikus yang memasuki fase estrus dapat dikawinkan dengan tikus jantan, apabila keesokan harinya ditemukan sumbat vagina maka tikus dinyatakan bunting. Setelah tikus dinyakatan bunting, tikus diinduksi terlebih dahulu dengan streptozotocin dengan dosis $40 \mathrm{mg} / \mathrm{kgBB}$ agar tikus mengalami hiperglikemia.
Pengukuran kadar glukosa darah dilakukan sebelum perlakuan dan hari ke-14 setelah perlakuan. Sebelum dilakukan pengambilan darah, tikus dipuasakan terlebih dahulu selama \pm 12 jam, kemudian tikus dibius dengan ketamin $40.08 \mathrm{mg} / \mathrm{kg}$ BB secara intramuskular hingga tidak sadarkan diri. Pengambilan darah dilakukan melalui plexus reorbitalis pada mata menggunakan pipa kapiler (Vogel 2008). Darah yang mengalir ditampung pada vacutte yang dipegang miring $45{ }^{\circ} \mathrm{C}$ kemudian dikocok. Darah yang diambil sebanyak $3 \mathrm{ml}$ lalu dipindahkan ke microtube kemudian disentrifugasi dengan kecepatan $4000 \mathrm{rpm}$ selama 15 menit agar diperoleh serum. Kemudian sampel siap dianalisis.

Serum diambil sebanyak $10 \mu \mathrm{l}$, dicampur dengan reagen enzim (pereaksi glukosa kit) sebanyak $1000 \mu \mathrm{l}$, kemudian divortex dan diinkubasi selama 5 menit pada suhu $37^{\circ} \mathrm{C}$ atau 10 menit pada suhu $20-25^{\circ} \mathrm{C}$. Baca kadar dengan spektrofotometer klinikal (Human 2012).

\section{Analisis Data}

Data yang diperoleh dianalisis secara statistik, mulamula diuji normalitas dan homogenitasnya. Setelah itu dilakukan uji analisis of varian (ANOVA) saru arah dengan taraf signifikansi 95\% $(p<0,05)$. Kemudian dilihat ada tidaknya perbedaan yang bermakna, jika terdapat perbedaan yang bermakna maka dilanjutkan dengan uji Tukey.

\section{HASIL DAN PEMBAHASAN}

Hasil dari Determinasi didapatkan bahwa simplisia yang digunakan dalam penelitian ini adalah Artocarpus heterophyllus Lam. dengan nama daerah nangka dan suku Moraceae . Determinasi tanaman bertujuan untuk mendapatkan kebenaran dari jenis tanaman uji yang akan digunakan dalam penelitian. Hasil Ekstraksi yang diperoleh pada Tabel 1 menunjukkan adanya penyusutan berat simplisia, mulai dari biji buah nangka segar hingga menjadi ekstrak kental etanol $70 \%$ biji buah nangka. Hal ini terjadi akibat adanya proses sortasi, pengeringan, hingga ekstraksi.

Tabel 1. Hasil ekstraksi biji buah nangka

\begin{tabular}{clc}
\hline No & \multicolumn{1}{c}{ Jenis } & Hasil \\
\hline 1 & Biji buah nangka segar & $4 \mathrm{~kg}$ \\
2 & Serbuk biji buah nangka & $1.700 \mathrm{~kg}$ \\
3 & Ekstrak kental etanol 70\% BBN & $171.39 \mathrm{~g}$ \\
\hline
\end{tabular}

Keterangan: BBN = Biji Buah Nangka 
Untuk mengetahui karakteristik dari ekstrak kental etanol $70 \%$ biji buah nangka maka dilakukan uji organoleptik. Uji ini dilakukan untuk mengetahui karakteristik dari ekstrak kental etanol $70 \%$ biji buah nangka meliputi bau, rasa, dan warna. Hasil uji dapat dilihat pada Tabel 2.

Penetapan Susut Pengeringan dilakukan untuk mengetahui besarnya senyawa yang hilang pada proses pengeringan. Persyaratan susut pengeringan menurut parameter standar yang berlaku adalah $<10 \%$ (Depkes 2000). Hasil susut pengeringan menunjukkan bahwa ekstrak kental etanol biji buah nangka memenuhi persyaratan maksimal susut pengeringan, yaitu $<10 \%$ (Tabel 3).

Uji penapisan fitokimia dilakukan untuk mengetahui kandungan kimia yang terdapat pada biji buah nangka. Penapisan fitokimia meliputi pemeriksaan senyawa alkaloid, flavonoid, tanin, steroid dan saponin pada ekstrak kental. Uji ini menunjukkan hasil positif untuk semua senyawa di atas. Hal ini disebabkan karena pelarut etanol mampu menarik semua zat dan bersifat pelarut universal (Tabel 4).

Tikus yang digunakan dalam percobaan yaitu jenis tikus putih (Ratus norvegicus) strain Sprague Dawley berasal dari Laboratorium Non Rominansia dan Satwa Harapan Fakultas Peternakan IPB. Tikus yang digunakan berumur 2-3 bulan sebanyak 24 ekor yang dibagi menjadi 6 kelompok yang masing-masing kelompok terdiri dari 4 ekor. Sebelum perlakuan tikus diaklimatisasi terlebih dahulu dikandang hewan selama 14 hari agar hewan percobaan dapat beradapatasi dengan lingkungan yang baru dan untuk mencukupkan bobot hewan percobaan dengan diberi minum dan pakan standar secukupnya.

Tikus di induksi streptozotosin (STZ). STZ merupakan zat diabetagonik yang mampu membuat hewan hiperglikemia. Mekanisme STZ masuk ke dalam sel $\beta$ pankreas melalui glucose transporter (GLUT2). Streptozotosin merusak sel $\beta$ pankreas sehingga menghambat produksi insulin dan terjadinya nekrosis pada sel $\beta$ pancreas. Sebelum tikus diberikan sediaan uji, pada hari ke-15 setelah diinduksi dilakukan pengecekan kadar gula darah sewaktu terhadap tikus untuk memastikan bahwa tikus tersebut sudah dalam kondisi hiperglikemia. Berdasarkan hasil pengecekkan kadar gula darah pada tikus kontrol negatif, positif dan

Tabel 2. Hasil karakteristik ekstrak kental etanol 70\% biji buah nangka

\begin{tabular}{llllc}
\hline \multirow{2}{*}{ No } & Jenis & \multicolumn{3}{c}{ Uji Organoleptik } \\
\cline { 3 - 5 } & Serbuk biji buah nangka & Bau & Rasa & Warna \\
\hline 1 & Ekstrak kental etanol 70\% BBN & Khas & Khas & Cokelat Muda \\
2 & Khas & Pahit & Cokelat \\
\hline
\end{tabular}

Keterangan: BBN = Biji Buah Nangka

Tabel 3. Hasil rendemen dan susut pengeringan ekstrak kental etanol $70 \%$ biji buah nangka

\begin{tabular}{|c|c|c|}
\hline No & Jenis & Hasil \\
\hline 1 & Rendemen Ekstrak Kental Etanol 70\% BBN & $10.08 \%$ \\
\hline 2 & Susut Pengeringan Ekstrak Kental Etanol 70\% BBN & $9.03 \%$ \\
\hline
\end{tabular}

Keterangan: BBN = Biji Buah Nangka

Tabel 4. Hasil penapisan fitokimia ekstrak kental etanol 70\% biji buah nangka

\begin{tabular}{clcc}
\hline No & \multicolumn{1}{c}{ Metabolit Sekunder } & $\begin{array}{c}\text { Ekstrak Kental } \\
\text { Etanol 70\% BBN }\end{array}$ \\
\hline 1 & Alkaloid & + \\
2 & Flavonoid & + \\
3 & Tanin & + \\
4 & Steroid & + \\
5 & Saponin & + \\
6 & Terpenoid & + \\
\hline
\end{tabular}

Keterangan: $(+)=$ mengandung senyawa 
uji didapatkan hasil rerata kadar gula darah sebesar $350.9 \pm 41.82 \mathrm{mg} / \mathrm{dL}$. Tikus tersebut sudah mengalami hiperglikemia karena kadar gula darah sewaktu sudah dikatakan hiperglikemia jika $>200 \mathrm{mg} / \mathrm{dL}$.

Pemberian ekstrak etanol $70 \%$ biji buah nangka dosis 1 , dosis 2, dan dosis 3 mampu menurunan kadar glukosa darah (Gambar 1). Berdasarkan pengujian statistik terhadap kadar glukosa darah akhir kelompok uji, diperoleh hasil uji normalitas dengan nilai $\mathrm{P}=0.054$ $>\alpha(0.05)$ artinya data terdistribusi normal. Hasil uji homogenitas diperoleh nilai $P=0.082>\alpha(0.05)$ sehingga data bervariasi homogen. Kemudian dilanjutkan dengan analisa menggunakan ANOVA satu arah. Hasil uji ANOVA satu arah terhadap penurunan kadar glukosa darah akhir diperoleh nilai $P=0.000<\alpha$ (0.05), hasil tersebut menunjukkan adanya perbedaan yang bermakna pada setiap kelompok perlakuan.

Data kemudiaan dilanjutkan dengan uji Tukey untuk mengetahui ada tidaknya perbedaan nilai penurunan kadar glukosa darah akhir yang bermakna antara masing-masing kelompok. Berdasarkan tabel Tukey diperoleh data bahwa hasil pengukuran menunjukkan $\mathrm{P}$ $<0.05$ yang berarti terdapat perbedaan nilai penurunan kadar glukosa darah yang bermakna antara kelompok kontrol positif dengan kelompok dosis 1, dan dosis 2 namun tidak terdapat perbedaan yang bermakna antara kelompok dosis 3 dan kontrol positif, hal ini menunjukan bahwa ekstrak etanol $70 \%$ biji buah nangka dengan dosis $400 \mathrm{mg} / \mathrm{kgBB}$ memiliki aktivitas lebih besar dibandingkan dengan dosis 1 dan 2, sebanding dengan kontrol positif metformin dengan dosis $51.37 \mathrm{mg} / \mathrm{kgBB}$.

Ekstrak etanol $70 \%$ biji buah nangka memiliki aktivitas menurunkan kadar glukosa sebanding dengan kontrol positif metformin. Pada penelitian ini dengan dosis $400 \mathrm{mg} / \mathrm{kgBB}$ ekstrak etanol biji buah nangka mampu menurunkan kadar glukosa darah pada tikus diabetes gestasional sebesar $61.73 \%$. Penurunan glukosa darah berkaitan dengan aktivitas biologis senyawa flavonoid dalam biji buah nangka. Senyawa yang terkandung dalam biji buah nangka yaitu flavonoid, alkaloid, saponin, steroid dan terpenoid. Senyawa flavonoid merupakan golongan senyawa yang dapat digunakan untuk menurunkan kadar glukosa darah.

Kandungan flavonoid diduga berperan secara signifikan meningkatkan aktivitas enzim antioksidan yang dapat menetralkan radikal bebas dan mampu menurunkan kadar gula darah dan mengatasi kelelahan yang diakibatkan oleh kadar gula darah yang tak seimbang. Flavonoid dapat menurunkan kadar glukosa darah dengan kemampuannya sebagai zat antioksidan

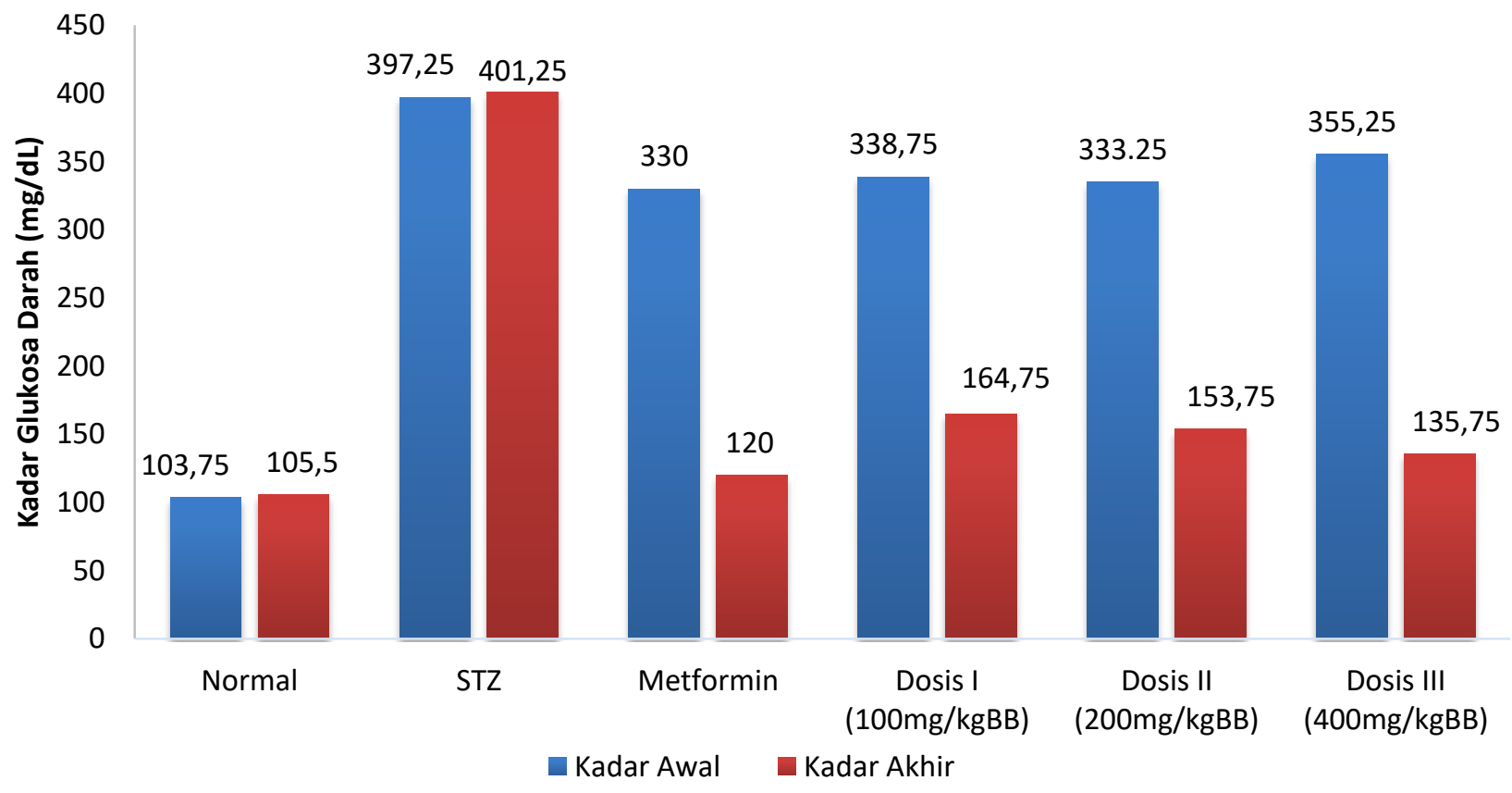

Gambar 1. Grafik Pengukuran Kadar Glukosa Darah

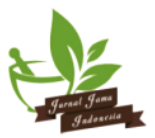


dan bersifat protektif terhadap kerusakan sel $\beta$ pankreas sebagai penghasil insulin serta dapat meningkatkan sensitivitas insulin.

\section{SIMPULAN}

Pemberian ekstrak etanol $70 \%$ biji buah nangka pada dosis 1 (100 mg/kgBB), dosis 2 (200mg/kgBB), dan dosis $3(400 \mathrm{mg} / \mathrm{kgBB})$ selama 14 hari mampu menurunkan kadar glukosa darah pada tikus diabetes mellitus gestasional. Dosis 3 memiliki potensi Penurunan kadar glukosa darah sebesar 61.73\%, sebanding dengan metformin.

\section{UCAPAN TERIMA KASIH}

Ucapan terima kasih penulis sampaikan kepada semua pihak yang membantu terlaksananya penelitian ini. Penulis ucapkan terima kasih juga kepada KEMENRISTEKDIKTI atas bantuan berupa dana penelitian Hibah Penelitian Dasar Unggulan Perguruan Tinggi tahun anggaran 2018 Nomor: 025/KM/PNT/2018.

\section{DAFTAR PUSTAKA}

ADA. 2009. Standars of Medical in Diabetes. Diabetes Care Vol 32.

ADA. 2016. Standart Of Medical Care in Diabetes. Diabetes Care. Vol 39.

Asmarawati RA. 2016. Karakteristik Amilum Biji Nangka (Artocarpus Heterophyllus Lamk.) dan Uji Aktivitas Antioksidan secara in-vitro. Skripsi. Fakultas ilmuilmu Kesehatan. Universitas Esa Unggul.

Brudenell M, Marjorie D. 1996. Diabetes pada kehamilan, diterjemahkan oleh Maulany, R. F., EGC, Jakarta.

Buchanan A, Thomas, dan Anny H. Xiang. 2005. Gestasional Diabetes Melitus. Los Angles (CA): University of Sothern California Keck School Of Medicine.

Departemen Kesehatan Republik Indonesia, 1997. Materia Medika. Edisi VII. Departemen Kesehatan Republik Indonesia, Jakarta.
Gupta D, Mann S, Sood A, dan Gupta RK. 2011. Phytochemical, Nutritional and Antioxidant Activity Evaluation of Seeds of Jackfruit (Artocarpus heterophyllus Lam.). International Journal of Pharma and Bio Sciences. 2(4):336-345. 30 November 2015.

Kaneto H, Kajimoto Y, Miyagawa J, Matsuoka T, Fujitani $Y$, Umayahara $Y$, Hanafusa $T$, Matsuzawa $Y$, Yamasaki Y, Hori N. 1999. Beneficial Effect of Antioxidant in Diabetes: Possible Protection of Pancreatic $\beta$ Cell Againt Glucose Toxicity. Diabetes. 48:2398-2406.

Moura L, Bezerra C, Nolaszo J, Mota L, Faloni S, Gomes O, Gaspari J, Dallarmi M. 2018. Acute and Subacute (28 days) toxicity, hemolytic and cytotoxin effect of Artocarpus heterophyllus seed extracts. Toxicology Reports. Brazil

Permana AW. 2009. Kulit Buah Manggis Dapat Menjadi Minuman Instan Kaya Antioksidan. Jurnal Penelitian Pascapanen Pertanian. 6(2): 100-123.

Rowan JA, Hague WM, Gao W, Battin MR, Moore MP. 2008. Metformin versus Insulin for the Treatment of Gestational Diabetes. The New England Journal of Medicine. 358 (19):2003-15.

Studiawan. 2007. Profil Kesehatan Indonesia: Pencapaian Indonesia Sehat Di Tahun 2001.

Swantara I MD, Darmayasa IBG, Dewi KA. 2011. Uji Aktivitas Antibakteri Fraksi Kulit Batang Nangka. Bukit Jimbaran (ID): Universitas Udayana.

Triplitt CL, Repas T, Alvarez C. 2015. Diabetes Mellitus. Dalam: Wells BG, Dipiro JT, Schwinghammer TL, Dipiro CV (Eds.). Pharmacoterapy Handbook. Edisi 9. New York: McGrew Hill Education. HIm. 161165.

Zanin JLB, Carvalho BA, Martineli PS, Santos MH, Lago, JHG, Sartorelli P, et al. 2012. The Genus Caesalpinia L. (Caesalpiniaceae): Phytochemical and Pharmacological Characteristics. Molecules. $7887-7902$. 